\title{
Pengaruh Leverage, Bonus Plan, Ukuran Perusahaan, dan Profitabilitas pada Praktik Perataan Laba
}

\author{
Made Anggi Adeliana Dewi ${ }^{1}$ \\ I Ketut Suryanawa ${ }^{2}$ \\ ${ }^{1,2}$ Fakultas Ekonomi dan Bisnis Universitas Udayana (Unud), Bali, Indonesia \\ e-mail:adelianadewi1104@gmail.com
}

\begin{abstract}
ABSTRAK
Penelitian dilakukan pada perusahaan industri barang konsumsi periode 2013-2017. Jumlah sampel penelitian sebanyak 165 pengamatan yang dipilih dengan metode non probability sampling yaitu purposive sampling. Penelitian ini menggunakan teknik analisis regresi logistik. Berdasarkan analisis tersebut, dapat diperoleh hasil yaitu bonus plan berpengaruh positif pada praktik perataan laba, ukuran perusahaan berpengaruh negatif pada praktik perataan laba, sedangkan leverage dan profitabilitas tidak pengaruh pada praktik perataan laba. Implikasi dari penelitian ini dapat dibagi menjadi dua jenis yaitu implikasi teoritis dan praktis. Implikasi teoritis yaitu dapat menjadi sumber referensi penelitian yang berkaitan dengan praktik perataan laba serta dapat mendukung teori keaganen dan teori akuntansi positif, sedangkan implikasi praktis yaitu menjadi bahan pertimbangan bagi investor dalam mengambil keputusan investasi.
\end{abstract}

Kata kunci: leverage, bonus plan, ukuran perusahaan, profitabilitas, praktik perataan laba

\begin{abstract}
The study was conducted on consumer goods industry companies for the period 2013-2017. The number of research samples is 165 observations chosen by non probability sampling method, namely purposive sampling. The data analysis technique uses logistic regression analysis. Based on the analysis, results can be obtained namely leverage does not affect the income smoothing practice; bonus plan has positive effect on income smoothing practices; company size has negative effect on income smoothing practices; and 4) profitability has no effect on income smoothing practices. The implications of this research can be divided into two types, namely theoretical and practical implications. Theoretical implications that can be a reference source of research relating to income smoothing practices and can support positive keaganen theory and accounting theory, while the practical implication is a consideration for investors in making investment decisions.
\end{abstract}

Keywords: leverage, bonus plan, company size, profitability, income smoothing practice

\section{PENDAHULUAN}

Pengguna laporan keuangan adalah pihak-pihak yang berkepentingan terhadap laporan keuangan itu sendiri. Pihak-pihak tersebut dapat berasal dari internal perusahaan seperti pemilik (owner) dan karyawan, serta pihak eksternal perusahaan seperti supplier, kreditur, investor, dan masyarakat umum (Astika, 2016:144). Laporan keuangan dan penggunanya dapat diibaratkan seperti telepon 
dan manusia. Manusia memperlukan telepon sebagai alat komunikasi, sama halnya dengan pengguna laporan keuangan yang memperlukan alat komunikasi berupa laporan keuangan untuk mengawasi kinerja perusahaan. Informasi yang berguna untuk mengawasi kinerja perusahaan adalah informasi laba.

Informasi laba merupakan salah satu informasi yang ada di laporan laba rugi dan cukup mendapatkan perhatian dari pengguna laporan keuangan. Informasi laba dapat digunakan untuk menilai kinerja manajemen perusahaan, memperkirakan risiko investasi yang mungkin terjadi, serta memperkirakan jumlah laba yang akan diperoleh di masa mendatang (Pramono, 2013). Dengan kata lain, kemampuan perusahaan untuk menghasilkan laba mencerminkan kemampuannya dalam mengelola kegiatan usaha. Pihak manajemen perusahaan sering kali merasa tertekan akibat tuntutan pekerjaan untuk mencapai target yang telah ditetapkan (Suryani dan Damayanti, 2015). Tekanan tersebut dapat menimbulkan konflik yang disebut dengan konflik keagenan.

Konflik keagenan terjadi karena agen diberikan kekuasaan oleh prinsipal untuk mengelola perusahaan. Adanya kekuasaan tersebut justru memberikan peluang bagi manajer untuk melakukan manipulasi laporan keuangan. Kasus manipulasi laporan keuangan pernah terjadi di Indonesia yaitu pada PT Kimia Farma. Berdasarkan hasil pemeriksaan, diperoleh bukti bahwa terdapat kesalahan dalam menyajikan laporan keuangan dimana dampaknya terjadi overstated laba pada laba bersihnya sebesar Rp32,6 miliar. Kasus lainnya juga pernah terjadi pada PT Indofarma, yang mana Bapepam membuktikan bahwa terjadi overstated pada 
nilai barang dalam proses tahun 2001 sebesar Rp28,87 miliar. Hal ini mengakibatkan laba bersih PT Indofarma mengalami overstated.

Disamping menunjukkan kinerja perusahaan yang baik, tindakan manipulasi laporan keuangan juga dilakukan untuk mengelola laba perusahaan agar terlihat stabil. Salah satu bentuk manipulasi laporan keuangan yaitu praktik perataan laba. Praktik perataan laba bertujuan untuk mengurangi fluktuasi laba perusahaan sehingga terlihat stabil (Obaidat, 2017). Laba yang stabil dapat memberikan rasa aman kepada pengguna laporan keuangan dan mendorong minat calon investor untuk menanamkan modalnya di perusahaan. Berikut ini terdapat data mengenai rata-rata laba perusahaan sektor industri barang konsumsi tahun 2013-2017 yang disajikan pada Gambar 1.

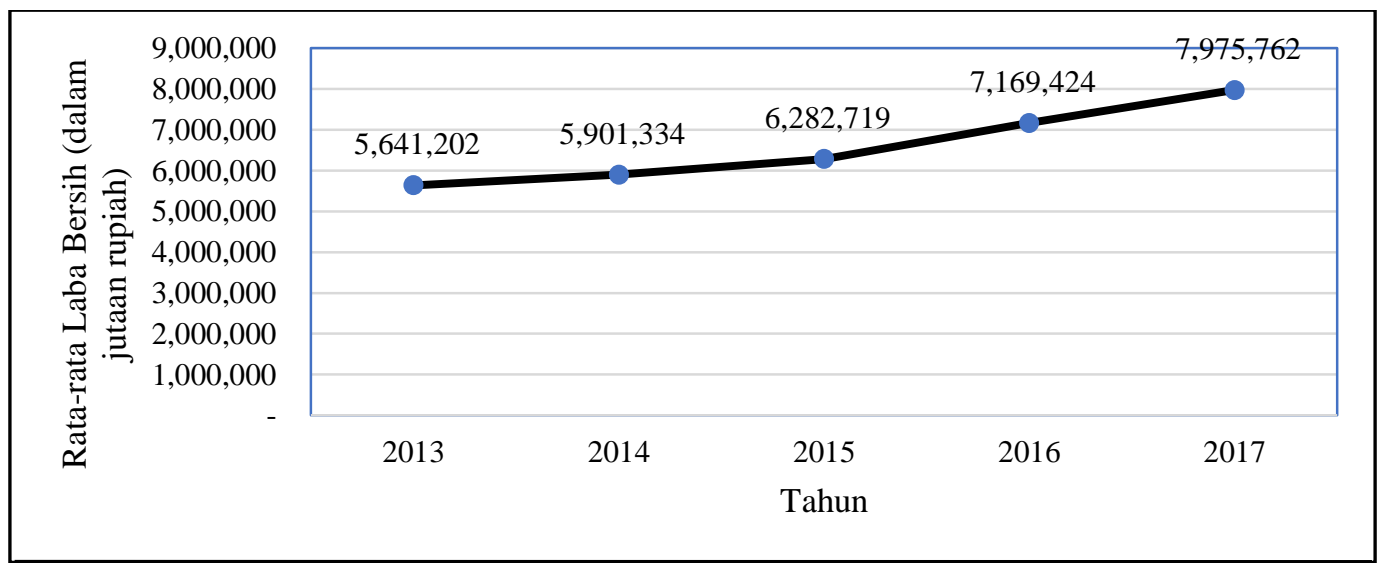

\section{Gambar 1. Rata-rata Laba Perusahaan Sektor Industri Barang Konsumsi Tahun 2013-2017}

Sumber: Data diolah, 2018

Berdasarkan Gambar 1 diperoleh bahwa rata-rata laba perusahaan sektor industri barang konsumsi tahun 2013-2017 selalu mengalami peningkatan. Ratarata laba tahun 2013 yaitu sebesar Rp5.641.202.000.000, dan meningkat sebesar 4,6\% atau Rp260.132.000.000 pada tahun 2014. Disamping itu, rata-rata laba 
tahun 2015 juga mengalami peningkatan sebesar 6,4\% dari rata-rata laba tahun 2014. Pada tahun 2016 dan 2017, rata-rata laba perusahaan meningkat masingmasing sebesar $14,1 \%$ dan $11,2 \%$. Dengan demikian, dapat disimpulkan bahwa peningkatan rata-rata laba yang tertinggi selama tahun 2013-2017 terjadi pada tahun 2016 yaitu 14,1\% atau sebesar Rp886.705.000.000

Praktik perataan laba merupakan tindakan yang sengaja dilakukan oleh manajemen perusahaan untuk mengurangi fluktuasi laba dengan cara memindahkan pendapatan yang tinggi dari suatu periode ke periode lainnya (Sari, 2014). Pihak manajemen perusahaan berusaha untuk mengelola labanya melalui dua cara tergantung dari situasi yang terjadi. Jika laba yang sebenarnya lebih kecil daripada laba yang diharapkan, maka pihak manajemen perusahaan akan memperbesar laba yang dilaporkan (Apriani dan Wirawati, 2018). Sebaliknya, jika laba sebenarnya lebih besar daripada laba yang diharapkan, maka pihak manajemen perusahaan akan memperkecil laba yang dilaporkan. Manajer cenderung melakukan praktik perataan laba karena disebabkan oleh beberapa faktor yang berasal dari dalam perusahaan.

Faktor pertama yang diduga dapat mempengaruhi praktik perataan laba adalah leverage. Tidak semua investasi yang dilakukan oleh perusahaan dapat dibiayai oleh modal sendiri, sehingga perusahaan dapat mencari dana lain yang berasal dari modal pinjaman. Maka dari itu, manajer perusahaan cenderung mengelola labanya agar terlihat stabil sehingga kepercayaan kreditur terhadap kemampuan perusahaan dalam membayar hutang juga akan meningkat. Enekwe et al., (2014) berpendapat bahwa motif utama perusahaan menggunakan utang yaitu 
untuk memperbesar tingkat pengembalian (return) dari investor. Pernyataan ini didukung oleh penelitian Putri dkk., (2016), Dwiputra dan Suryanawa (2016), serta Putri dan Budiasih (2018) yaitu leverage berpengaruh positif terhadap praktik perataan laba, tetapi Handayani dan Fuad (2015) memperoleh bukti empiris bahwa leverage berpengaruh negatif terhadap praktik perataan laba.

Tabel 1.

Rata-rata Debt Equity Ratio (DER) dari Perusahaan Sektor Industri Barang Konsumsi Tahun 2013-2017

\begin{tabular}{llccccc}
\hline \multirow{2}{*}{ No. } & \multicolumn{1}{c}{ Sub Sektor } & $\mathbf{2 0 1 3}$ & $\mathbf{2 0 1 4}$ & $\mathbf{2 0 1 5}$ & $\mathbf{2 0 1 6}$ & $\mathbf{2 0 1 7}$ \\
\hline 1. & Makanan dan minuman & 82,54 & 108,92 & 98,31 & 92,76 & 81,38 \\
2. & Rokok & 259,59 & $-197,31$ & $-98,19$ & 34,70 & 35,26 \\
3. & Farmasi & 50,06 & 45,74 & 52,29 & 53,21 & 64,83 \\
4. & Kosmetik dan barang & 71,69 & 78,87 & 85,51 & 94,08 & 101,47 \\
& keperluan rumah tangga & 76,00 & 76,00 & 70,50 & 78,00 & 92,50 \\
5. & Peralatan rumah tangga & 7 & & & & \\
\hline
\end{tabular}

Sumber: Data diolah, 2018

Berdasarkan Tabel 1, diperoleh bahwa perusahaan sub sektor makanan dan minuman memiliki rata-rata DER yang cukup tinggi dibandingkan dengan empat sub sektor lainnya. Hal ini disebabkan karena rata-ratanya berada diatas $90 \%$. DER yang tinggi menunjukkan bahwa ketergantungan perusahaan terhadap kreditur semakin tinggi dan risiko yang dihadapi perusahaan juga semakin tinggi, sehingga perusahaan akan mengalami kesulitan untuk memperoleh tambahan modal dari kreditur. Maka dari itu, manajer pada perusahaan memiliki kecenderungan untuk mengelola labanya melalui praktik perataan laba.

Faktor lain yang diduga mempengaruhi praktik perataan laba yaitu bonus plan. Bonus plan merupakan salah satu bentuk penghargaan perusahaan terhadap kinerja manajer (Nugroho dan Darsono, 2015). Pada perusahaan yang memiliki kompensasi bonus, manajer akan berupaya untuk menghasilkan laba sesuai dengan target yang telah ditetapkan sebelumnya sehingga manajer mampu 
Made Anggi Adeliana Dewi dan I Ketut Suryanawa. Pengaruh...

memperoleh bonus. Motivasi bonus mendorong manajer perusahaan melakukan praktik perataan laba. Penelitian Gayatri dan Wirakusuma (2013) menemukan bahwa kompensasi bonus akan memicu manajer perusahaan untuk melakukan praktik perataan laba, sedangkan Natalie dan Astika (2016) menemukan bahwabonus plan tidak berpengaruh terhadap income smoothing.

Faktor ketiga yang diduga mempengaruhi praktik perataan laba yaitu ukuran perusahaan. Perusahaan besar akan mendapatkan pengawasan yang lebih ketat pengguna laporan keuangan dibandingkan dengan perusahaan kecil. Perusahaan besar dengan laba yang tinggi akan mendapatkan pengawasan dan perhatian dari pemerintah, salah satunya dalam hal pajak (Zuhriya dan Wahidahwati, 2015). Pada umumnya, perusahaan enggan untuk membayar pajak yang tinggi sehingga mendorong manajer pada perusahaan besar melakukan praktik perataan laba. Penelitian Fadhli (2015), Lahaya (2017), serta Pratiwi dan Damayanthi (2017) membuktikan bahwa ukuran perusahaan berpengaruh positif pada praktik perataan laba. Disamping itu, penelitian Wahyuni dkk., (2013), Fatmawati dan Djajanti (2015), serta Sidartha dan Erawati (2017) menemukan hasil yang berbeda yaitu ukuran perusahaan berpengaruh negatif pada praktik perataan laba.

Faktor keempat yang diduga mendorong timbulnya praktik perataan laba adalah profitabilitas. Perusahaan yang memiliki tingkat profitabilitas tinggi menunjukkan bahwa kinerja perusahaan baik. Perusahaan dengan tingkat profitabilitas yang rendah menunjukkan kinerja perusahaan yang kurang baik sehingga dapat berisiko terhadap pemberian dividen dan sulit untuk menarik 
perhatian pihak eksternal perusahaan. Oleh karena itu, tingkat profitabilitas suatu perusahaan juga menjadi motivasi manajer dalam mengelola labanya. Penelitian Herlina dan Damayanthi (2016), Iskandar dan Suardana (2016), serta Trisnawati dkk., (2017) menjelaskan bahwa profitabilitas memiliki pengaruh negatif pada praktik perataan laba, namun Muslichah (2015), Dewi dan Latrini (2016), serta Eni dan Suaryana (2018) menemukan bukti empiris bahwa perusahaan dengan tingkat profitabilitas tinggi cenderung melakukan praktik perataan laba.

Adapun tujuan dari penelitian ini yaitu membuktikan pengaruh leverage, bonus plan, ukuran perusahaan, dan profitabilitas pada praktik perataan laba. Kegunaan dari penelitian ini terdiri atas manfaat teoretis yaitu mendukung teori yang berkaitan dengan perataan laba, seperti teori keagenan dan teori sinyal, teori akuntansi positif, serta memberikan bukti empiris terkait pengaruh leverage, bonus plan, ukuran perusahaan, dan profitabilitas pada praktik perataan laba.Disamping itu, penelitian ini juga diharapkan memiliki manfaat praktis yaitu memberikan tambahan informasi sekaligus sebagai bahan pertimbangan bagi pengguna laporan keuangan dalam mengambil keputusan investasi.

Jensen dan Meckling (1976) menjelaskan bahwa hubungan agensi adalah hubungan kontraktual antara prinsipal dan agen, yang mana prinsipal mendelegasikan wewenangnya kepada agen, sedangkan agen wajib mempertanggungjawabkan pekerjaannya kepada prinsipal. Prinsipal sebagai pemilik modal mempunyai hak untuk memperoleh informasi berkaitan dengan internal perusahaan, sedangkan agen bertindak sebagai pengelola modal (manajemen perusahaan). Dalam teori keagenan, terdapat tiga sifat dasar manusia 
yang dapat memicu konflik agensi seperti seft interest, bounded rationality, dan risk averse (Eisenhardt, 1989).

Dalam praktiknya, distribusi informasi antara agen dengan prinsipal yang tidak sama dapat disebabkan karena manajer sebagai agen berada di dalam perusahaan sehingga memiliki informasi yang lebih banyak mengenai kondisi perusahaan. Ketidakseimbangan informasi itulah yang disebut dengan asimetri informasi. Asimetri informasi dapat terjadi ketika agen tidak mengungkapkan seluruh informasi mengenai kinerja perusahaan yang dimilikinya kepada prinsipal (Liu, 2012).

Teori sinyal merupakan teori yang berguna untuk menggambarkan perilaku dari dua pihak yang memiliki akses berbeda terhadap suatu informasi (Connelly et al., 2011). Agen mengetahui informasi perusahaan dibandingkan dengan prinsipal sehingga informasi tersebut diharapkan dapat menjadi sinyal mengenai kondisi perusahaan. Hal ini juga disebabkan karena investor mengalami kesulitan dalam membedakan kinerja perusahaan yang baik dan kinerja perusahaan yang buruk. Informasi dapat diterjemahkan sebagai sinyal yang baik dan sinyal yang buruk. Salah satu contoh sinyal yang baikyaitu informasi tentang peningkatan laba perusahaan, sedangkan penurunan laba dapat dikatakan sebagai sinyal yang buruk (Zuhriya dan Wahidahwati, 2015).

Teori akuntansi positif mengasumsikan bahwa manajer, pemegang saham, dan pengguna lapora keuangan lainnya adalah rasional dan berusaha untuk memaksimalkan kepentingannya. Watts dan Zimmerman (1978) merumuskan tiga hipotesis pada teori ini yaitu hipotesis rencana bonus, hipotesis kebijakan hutang, 
dan hipotesis biaya politik. Hipotesis rencana bonus berkaitan dengan adanya rencana pemberian bonus dapat mendorong manajer untuk memilih metode akuntansi yang dapat mengubah atau menggeser laba periode yang akan datang ke laba periode sekarang. Hipotesis kebijakan hutang berkaitan dengan kecenderungan manajer yang menaikkan laba, sebab perusahaan memiliki rasio debt to equityyang tinggi. Hipotesis biaya politik berkaitan dengan kecenderungan manajer untuk menurunkan laba sebab tingginya biaya politik perusahaan.

Fischer dan Rosenzweig (1995) berpendapat bahwa manajemen laba adalah serangkaian langkah yang dilakukan manajer dalam mengatur jumlah laba tahun berjalan dengan cara meningkatkan atau menurunkan laba. Praktik perataan laba merupakan pola atau bentuk dari manajemen laba. Hejazi et al.,(2011) menjelaskan bahwa praktik perataan laba merupakan tindakan manajemen untuk meredam fluktuasi laba yang dilaporkan dari waktu ke waktu yang bertujuan untuk mengurangi jumlah pajak yang terutang, memperbaiki citra perusahaan, dan meningkatkan kepercayaan investor serta kreditur. Perataan laba juga dapat dijelaskan sebagai tindakan yang disengaja untuk mengurangi fluktuasi laba di sekitar tingkat laba tertentu agar dianggap normal bagi sebuah perusahaan (Beidleman, 1973).

Manajer melakukan perataan laba karena ada motivasi yang mendasarinya. Ada dua pemikiran yang menjelaskan motivasi seorang manajer untuk melakukan praktik perataan laba (Aflatooni dan Nikbakht, 2009). Pemikiran yang pertama menjelaskan bahwa praktik perataan laba dapat dianggap sebagai sarana atau alat bagi manajer untuk mengungkapkan informasi pribadi yang dimilikinya. 
Pemikiran kedua menjelaskan bahwa praktik perataan laba sebagai upaya untuk mengelabuhi atau menipu pihak yang berkepentingan terhadap perusahaan.

Manajemen perusahaan dapat melakukan praktik perataan laba melalui dua cara, baik secara sengaja maupun tidak sengaja. Yulia (2013) mengungkapkan bahwa perataan laba dapat digolongkan menjadi naturally smooth dan intentionally being smoothed by management. Naturally smoothartinya perataan laba yang terjadi pada perusahaan tidak diintervensi oleh pihak-pihak tertentu. Intentionally being smoothed by management memiliki arti bahwa perataan laba yang terjadi pada perusahaan merupakan tindakan yang akibat adanya intervensi pihak manajemen, misalnya adanya penjualan fiktif pada suatu periode tertentu.

Leverage merupakanrasio yang menunjukkan sejauh mana perusahaan dibiayai oleh modal pinjaman (Wiagustini, 2014:88). Menurut teori keagenan, manajer lebih mengetahui kondisi perusahaan dibandingkan kreditur. Hipotesis kebijakan hutang juga menjelaskan bahwa manajer pada perusahaan yang memiliki tingkat hutang yang tinggi akan menggunakan metode akuntansi yang dapat mengelola labanya. Hal ini disebabkan karena perusahaan dengan kondisi tersebut akan terancam bangkrut, sehingga manajemen akan membuat kebijakan untuk menaikkan laba.Dwiputra dan Suryanawa (2016) berpendapat bahwa leverage berpengaruh positif pada praktik perataan laba.

$\mathrm{H}_{1}$ : Leverage berpengaruh positif pada praktik perataan laba.

Bonus plan atau kompensasi bonus merupakan salah satu bentuk penghargaan yang diberikan kepada manajer perusahaan atas jasa dan pengorbanan yang dilakukan (Elfira, 2014). Berdasarkan teori keagenan, manajer 
memiliki kepentingan untuk meningkatkan bonus. Hipotesis rencana bonus juga menjelaskan manajer di perusahaan yang memiliki rencana bonus cenderung memilih metode akuntansi yang dapat menggeser laba periode yang akan datang ke laba periode sekarang. Adanya pemberian bonus yang diberikan kepada manajer diduga dapat mendorong manajer untuk melakukan praktik perataan laba. Gayatri dan Wirakusuma (2013) menemukan bahwa bonus plan berpengaruh positif pada praktik perataan laba.

$\mathrm{H}_{2}$ : Bonus plan berpengaruh positif pada praktik perataan laba.

Ukuran perusahaan merupakan skala untuk mengklasifikasikan besar atau kecilnya suatu perusahaan (Yusrilandari, 2016). Berdasarkan hipotesis biaya politik, manajer cenderung memilih metode akuntansi untuk menurunkan laba apabila biaya politik perusahaan cukup tinggi. Martinez dan Castro (2011) mengungkapkan bahwa perusahaan besar cenderung melakukan praktik perataan laba karena berada di bawah pengawasan pembuat kebijakan publik, seperti pemerintah maupun masyarakat umum. Hal ini juga didukung oleh Fadhli(2015) yang membuktikan bahwa manajer pada perusahaan besar cenderung melakukan praktik perataan laba dibandingkan dengan perusahaan yang lebih kecil. $\mathrm{H}_{3}$ : Ukuran perusahaan berpengaruh positif pada praktik perataan laba.

Profitabilitas merupakan rasio untuk mengetahui kemampuan perusahaan dalam menghasilkan laba (Bestivano, 2013). Tingginya tingkat profitabilitas akan menunjukkan bahwa perusahaan tersebut memiliki kinerja yang baik sehingga mendapat perhatian lebih dari investor. Sebaliknya, perusahaan yang tingkat profitabilitasnya rendah akan sulit mendapatkan perhatian investor. Wang dan 
William (2011) menjelaskan bahwa investor lebih tertarik membeli saham perusahaan dengan laba yang stabil dibandingkan perusahaan dengan fluktuasi laba yang tinggi

$\mathrm{H}_{4}$ : Profitabilitas berpengaruh negatif pada praktik perataan laba.

\section{METODE PENELITIAN}

Desain yang digunakan pada penelitian ini menggunakan pendekatan asosiatif, yang menjelaskan pengaruh variable bebas pada variabel terikat. Penelitianini dilakukan pada perusahaan sektor industri barang konsumsiyang terdaftar di Bursa Efek Indonesia (BEI) periode 2013-2017. Data dari perusahaan tersebut diperoleh dengan mengakses www.idx.co.id, www.sahamok.com, www. cdn.indonesia-investments.com, dan website resmi dari masing-masing perusahaan.

Variabel bebas dalam penelitian ini yaitu leverage $\left(\mathrm{X}_{1}\right)$, bonus plan $\left(\mathrm{X}_{2}\right)$, ukuran perusahaan $\left(\mathrm{X}_{3}\right)$, dan profitabilitas $\left(\mathrm{X}_{4}\right)$, sedangkan variabel terikatnya adalah praktik perataan laba (Y). Variabel bebas pertama yaitu leverage yang diproksikan dengan DER untuk mengukur kemampuan perusahaan dalam membayar seluruh hutangnya dengan modal perusahaan. DER dapat dihitung dengan rumus sebagai berikut (Kasmir, 2013: 158).

$$
\text { DER }=\frac{\text { Total Hutang }}{\text { Total Ekuitas }}
$$

Variabel bebas kedua yaitu bonus plan, yang mana variable dummy digunakan untuk mengukur bonus plan itu sendiri. Nilai 1 diberikan kepada perusahaan yang memberikan bonus. Sebaliknya, apabila perusahaan tidak memberikan bonus maka akan diberikan nilai 0 . 
Variabel bebas ketiga pada penelitian ini adalah ukuran perusahaan. Ukuran perusahaan dihitung menggunakan logaritma natural total asset. Adapun rumusnya yaitu sebagai berikut (Josep dkk., 2016).

Ukuran Perusahaan $=\ln$ Total Aset

Variabel bebas keempat pada penelitian ini adalah profitabilitas. Profitabilitas diproksikan dengan menggunakan rasio ROE untuk mengetahui tingkat efisiensi penggunaan ekuitasdalam menghasilkan laba.Rasio ini merupakan indikator kunci dari kinerja manajemen karena mampu mengukur laba atas modal yang telah ditanamkan oleh pihak investor (Saeidi, 2012). ROE $=\frac{\text { Laba Bersih Setelah Pajak }}{\text { Total Ekuitas }}$

Praktik perataan laba dihitung dengan menggunakan Indeks Eckel. Nejad dan Alavi(2013) berpendapat bahwa Indeks Eckel digunakan sebab indeks ini menggunakan periode beberapa tahun dan tidak menggunakan penilaian subyektif. Perusahaan dengan Indeks Eckellebih kecil dari 1 akan digolongkan sebagai perusahaan perata laba (skor 1). Sebaliknya, perusahaan dengan Indeks Eckel yang lebih besar atau sama dengan 1 akan digolongkan sebagai perusahaan tidak perata laba (skor 0). Adapun rumusnya yaitu sebagai berikut (Eckel, 1981).

$$
\begin{aligned}
& \text { Indeks Eckel }=\frac{\mathrm{CV} \Delta \mathrm{I}}{\mathrm{CV} \Delta \mathrm{S}} \ldots \ldots . . \\
& \mathrm{CV} \Delta \mathrm{I}=\sqrt{\frac{\sum\left(\Delta \mathrm{I}-\overline{\Delta \mathrm{I}}^{2}\right.}{\mathrm{n}-1}: \overline{\Delta \mathrm{I}} \ldots .} \\
& \mathrm{CV} \Delta \mathrm{S}=\sqrt{\frac{\sum\left(\Delta \mathrm{S}-\overline{\Delta \mathrm{S}}^{2}\right.}{\mathrm{n}-1}}: \overline{\Delta \mathrm{S}} \ldots
\end{aligned}
$$


Keterangan :

$\Delta \mathrm{I}=$ Perubahan laba antara tahun $\mathrm{n}$ ke tahun $\mathrm{n}-1$

$\Delta \mathrm{S}=$ Perubahan pendapatan antara tahun $\mathrm{n}$ ke tahun $\mathrm{n}-1$

$\mathrm{CV}=$ Koefisien variasi

$\bar{\Delta} \mathrm{I}=$ Perubahan rata-rata laba antara tahun $\mathrm{n}$ ke tahun $\mathrm{n}-1$

$\overline{\Delta \mathrm{S}}=$ Perubahan rata-rata pendapatan antara tahun $\mathrm{n}$ ke tahun $\mathrm{n}-1$

$\mathrm{n}=$ Periode pengamatan

Populasi penelitian ini yaitu seluruh perusahaan sektor industri barang konsumsi yang terdaftar pada BEI, dengan purposive sampling sebagai metode pengambilan sampel yaitu teknik penentuan sampel dengan menggunakan beberapa kriteria tertentu. Adapun kriteria yang digunakan untuk menentukan sampel dalam penelitian ini adalah: 1) Perusahaan sektor industri barang konsumsi yang terdaftar di BEI periode 2013-2017. 2) Perusahaan sektor industri barang konsumsi yang secara berturut-turut mempublikasikan laporan keuangan tahunan periode 2013-2017.

Penelitian ini menggunakan data kuantitatif, artinya data yang digunakan berupa informasi dalam bentuk angka atau bilangan. Data tersebut merupakan angka-angka yang disajikan pada laporan keuangan perusahaan. Disamping itu, sumber data pada penelitian ini adalah data sekunder yang berasal dari laporan tahunan perusahaan sektor industri barang konsumsi, dan diperoleh melalui website resmi BEI. Observasi nonpartisipan merupakan metode pengumpulan data yang digunakan pada penelitian ini, sedangkan teknik analisis yang digunakan yaitu analisis regresi logistik melalui program SPSS. Teknik analisis ini digunakan karena praktik perataan laba sebagai variabel terikat merupakan variabel dummy. Adapun persamaan regresi yang terbentuk yaitu.

$\ln \frac{p}{1-p}=\alpha+\beta_{1} X_{1}+\beta_{2} X_{2}+\beta_{3} X_{3}+\beta_{4} X_{4}+\varepsilon$ 
Keterangan: $\ln \frac{\mathrm{p}}{1-\mathrm{p}}=\begin{aligned} & \text { Perusahaan melakukan praktik perataan laba(melakukan } \\ & \text { variabel dummy, } 0 \text { untuk perusahaan bukan perata laba, } 1\end{aligned}$ untuk perusahaan perata laba)

$$
\begin{array}{ll}
\alpha & =\text { Konstanta regresi } \\
\beta_{1}-\beta_{5} & =\text { Koefisien regresi } \\
\mathrm{X}_{1} & =\text { Leverage } \\
\mathrm{X}_{2} & =\text { Bonus plan } \\
\mathrm{X}_{3} & =\text { Ukuran Perusahaan } \\
\mathrm{X}_{4} & =\text { Profitabilitas } \\
\varepsilon & =\text { Error term }
\end{array}
$$

\section{HASIL DAN PEMBAHASAN}

Tabel 2.

Hasil Statistik Deskriptif

\begin{tabular}{lrrrrr}
\hline & N & Minimum & Maximum & \multicolumn{1}{c}{ Mean } & Std. Deviation \\
\hline X1 & 165 & $-9,447$ & 8,886 & 0,65148 & 1,220690 \\
X2 & 165 & 0 & 1 & 0,36 & 0,481 \\
X3 & 165 & 25,311 & 32,108 & 28,50473 & 1,434425 \\
X4 & 165 & $-1,757$ & 1,420 & 0,13240 & 0,292624 \\
Y & 165 & 0 & 1 & 0,50 & 0,502 \\
Valid N (listwise) & 165 & & & & \\
\hline \multicolumn{2}{l}{ Sumber: Data diolah, 2018 } & & &
\end{tabular}

Leverage (X1) memiliki nilai minimum sebesar -9,447 (PT Bentoel

Internasional Investama Tbk tahun 2014), sedangkan nilai maksimumnya sebesar 8,886 (PT Bentoel Internasional Investama Tbk tahun 2013). Nilai rata-rata dari leveragesebesar 0,65148, yang berarti bahwa rata-rata setiap Rp100 modal perusahaan dapat menjamin hutang sebesar Rp65,15. Nilai standar deviasi leverage sebesar 1,220690.

Bonus plan (X2) merupakan variabel dummy. Nilai 1 diberikan untuk perusahaan yang memberikan bonus pada tahun tertentu, sedangkan nilai 0 untuk perusahaan tidak memberikan bonus pada tahun tertentu. Nilai rata-rata bonus plan sebesar 0,36 yang berarti bahwa $36 \%$ dari jumlah pengamatan memberikan 
bonus, sedangkan sisanya sebesar $64 \%$ dari jumlah pengamatantidak memberikan bonus. Nilai standar deviasi bonus plan sebesar 0,481.

Tabel 3.

Hasil Uji Hosmer dan Lemeshow

\begin{tabular}{lcccc}
\hline \multicolumn{1}{c}{ Step } & Chi-square & Df & Sig. \\
\hline 1 & 7,131 & & 8 & 0,523 \\
\hline Sumber: Data diolah, 2018 & & & &
\end{tabular}

Berdasarkan Tabel 3, nilai Chi-square yaitu 7,131 dan nilai signifikansi sebesar 0,523 (lebih besar dari 0,05). Dengan demikian, model cocok dengan data observasinya atau model dapat diterima.

Tabel 4.

Perbandingan Nilai -2LL Awal dengan Nilai -2LL Akhir

\begin{tabular}{cc}
\hline -2LL awal (Block Number $=0)$ & 228,733 \\
\hline -2LL akhir (Block Number $=1)$ & 194,949 \\
\hline Sumber: Data diolah, 2018
\end{tabular}

Tabel 3 menjelaskan nilai -2LL awal yaitu sebesar 228,733 dan nilai -2LL akhir mengalami penurunan menjadi 194,949. Penurunan nilai -2LL tersebut menunjukkan bahwa model regresi yang diuji dapat dikatakan baik, artinya model yang dihipotesiskan fit dengan data.

Tabel 5.

Hasil Uji Koefisien Determinasi

\begin{tabular}{|c|c|c|c|}
\hline Step & -2 Log likelihood & $\begin{array}{c}\text { Cox \& Snell R } \\
\text { Square }\end{array}$ & Nagelkerke R Square \\
\hline 1 & $194,949^{\mathrm{a}}$ & 0,185 & 0,247 \\
\hline
\end{tabular}

Tabel 4 menunjukkan nilai Nagelkerke $R$ Square yaitu sebesar 0,247 atau 24,7\%. Nilai tersebut memiliki arti bahwa variabel terikat dipengaruhi oleh variabel bebas hanya sebesar $24,7 \%$, dan sebesar 75,3\% dipengaruhi oleh variabel bebas lainnya yang tidak dimasukkan dalam penelitian ini. 
Tabel 6.

Matriks Korelasi

\begin{tabular}{rlrrrrr}
\hline & & Constant & \multicolumn{1}{c}{ X1 } & \multicolumn{1}{c}{ X2 } & \multicolumn{1}{c}{ X3 } & \multicolumn{1}{c}{ X4 } \\
\hline Step 1 & Constant & 1,000 & 0,030 & $-0,017$ & $-0,997$ & 0,293 \\
& X1 & 0,030 & 1,000 & 0,093 & $-0,083$ & 0,237 \\
& X2 & $-0,017$ & 0,093 & 1,000 & $-0,015$ & $-0,078$ \\
& X3 & $-0,997$ & $-0,083$ & $-0,015$ & 1,000 & $-0,327$ \\
& X4 & 0,293 & 0,237 & $-0,078$ & $-0,327$ & 1,000 \\
\hline
\end{tabular}

Sumber: Data diolah, 2018

Berdasarkan Tabel 6 nilai koefisien korelasi antar variabel yaitu lebih kecil dari 0,8 atau dengan kata lain tidak ada koefisien korelasi antar variabel yang nilainya lebih besar dari 0,8 . Hal ini berarti bahwa model regresi pada penelitian ini tidak mengandung gejala multikolinearitas yang serius antar variabel bebas.

Tabel 7.

Matriks Klasifikasi

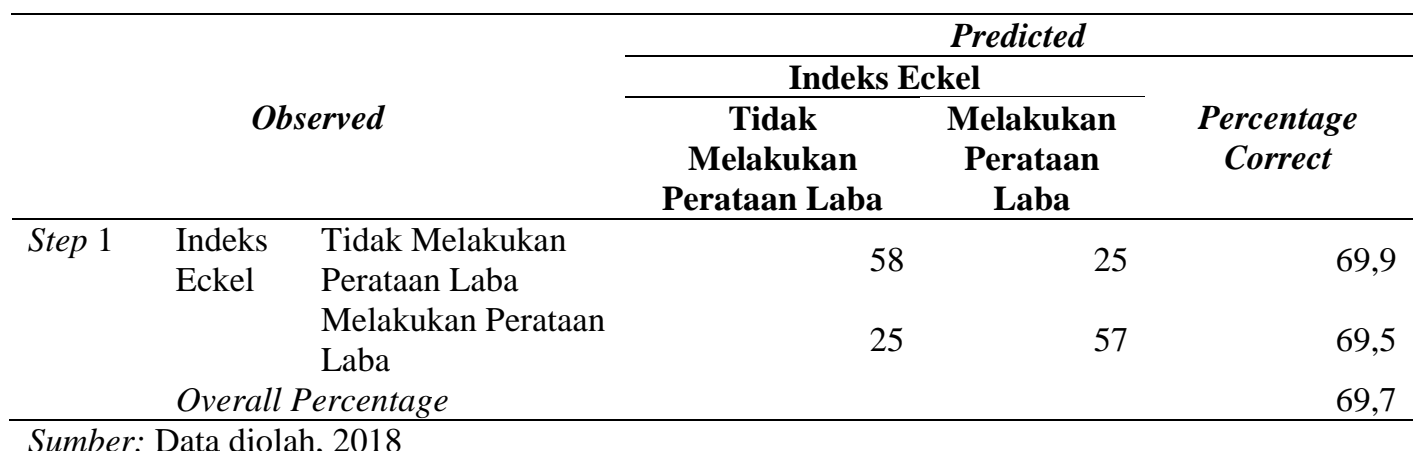

Tabel 7menjelaskan bahwa model regresi mempunyai kemampuan untuk memprediksi kemungkinan perusahaan tidak melakukan praktik perataan laba yaitu $69,9 \%$. Nilai tersebut menunjukkan bahwa 83 jumlah pengamatan yang tidak melakukan perataan laba terdiri atas 58 jumlah pengamatan yang diprediksi tidak melakukan perataan laba, dan 25 jumlah pengamatan melakukan perataan laba. Kekuatan prediksi kemungkinan perusahaan melakukan praktik perataan laba yaitu $69,5 \%$. Nilai tersebut menunjukkan bahwa 82 jumlah pengamatan yang melakukan perataan laba terdiri atas 25 jumlah pengamatan diprediksi tidak 
melakukan perataan laba, sisanya 57 jumlah pengamatan diprediksi melakukan perataan laba.

Tabel 8.

Hasil Uji Regresi Logistik

\begin{tabular}{rlrrrrrr}
\hline & & B & S.E. & Wald & df & Sig. & \multicolumn{1}{c}{$\operatorname{Exp(B)~}$} \\
\hline Step $1^{\text {a }}$ & X1 & 0,187 & 0,241 & 0,604 & 1 & 0,437 & 1,206 \\
& X2 & 1,039 & 0,368 & 7,949 & 1 & 0,005 & 2,826 \\
& X3 & $-0,581$ & 0,144 & 16,172 & 1 & 0,000 & 0,560 \\
& X4 & 1,672 & 0,934 & 3,209 & 1 & 0,073 & 5,327 \\
& Constant & 15,781 & 4,051 & 15,175 & 1 & 0,000 & 7.146 .489 \\
\hline
\end{tabular}

Sumber: Data diolah, 2018

Persamaan model regresi logistik yang dihasilkan yaitu sebagai berikut.

$$
\ln \frac{\mathrm{p}}{1-\mathrm{p}}=15,781+0,187 \mathrm{X}_{1}+1,039 \mathrm{X}_{2}-0,581 \mathrm{X}_{3}+1,672 \mathrm{X}_{4}+\varepsilon
$$

Berdasarkan model regresi yang terbentuk, maka hasilnya dapat diinterpretasikan sebagai berikut.Nilai konstanta sebesar 15,781 artinya jika leverage, bonus plan, ukuran perusahaan, dan profitabilitas dianggap konstan maka kemungkinan perusahaan melakukan praktik perataan laba akan mengalami peningkatan yaitu sebesar 15,781.

Koefisien regresi dari leverage yaitu 0,187 dengan nilai signifikansi sebesar 0,437 (>0,05), yang berarti bahwa leverage tidak berpengaruh pada praktik perataan laba atau $\mathrm{H}_{1}$ ditolak. Tinggi atau rendahnya tingkat leverage perusahaan tidak mempengaruhi manajer melakukan praktik perataan laba. Hal ini dapat dijelaskan dengan nilai rata-rata pada hasil statistik deskriptif. Secara umum, rata-rata leverage pada perusahaan sampel yaitu sebesar 0,65148 atau $65,15 \%$. Nilai tersebut berada dibawah standar industri sebesar $90 \%$ yang berarti bahwa rata-rata leverage pada perusahaan sampel masih tergolong rendah. Oleh karena itu, penelitian ini belum mampu membuktikan adanya hubungan positif antara leverage dengan praktik perataan laba. 
Tidak berpengaruhnya leverage pada praktik perataan laba menunjukkan bahwa motivasi manajer untuk melakukan praktik perataan laba tidak bergantung pada tingkat leverage perusahaan. Hal tersebut dapat disebabkan karena adanya penerapan tata kelola yang baik di perusahaan atau sering disebut dengan good corporate governance. Corporate governance merupakan suatu sistem dalam mengatur dan mengendalikan perusahaan yang berdasarkan pada peraturan perundang-undangan, dengan tetap memperhatikan kepentingan dari para stakeholders sehingga dapat memberikan nilai tambah bagi perusahaan (Putri dan Ulupui, 2017:4).

Penerapan good corporate governance dalam suatu perusahaan mampu mengurangi kesempatan manajer perusahaan untuk berperilaku oportunis. Penelitian Pande dan Suryanawa (2017) membuktikan bahwa good corporate governance mampu memperlemah pengaruh leverage pada praktik perataan laba. Hal ini berarti bahwa penerapan good corporate governance dapat membantu pihak prinsipal untuk mengawasi kinerja manajer. Jadi, semakin baik penerapan tata kelola di dalam perusahaan maka semakin kecil kemungkinan manajer untuk melakukan praktik perataan laba.

Koefisien regresi dari bonus planyaitu 1,039 dengan nilai signifikansi sebesar $0,005(<0,05)$, yang berarti bahwa bonus planberpengaruh positif pada praktik perataan labaatau $\mathrm{H}_{2}$ diterima. Maka dari itu, semakin besar bonus plan atau kompensasi bonus yang diterima oleh manajer maka peluang manajer untuk melakukan praktik perataan laba juga akan meningkat. 
Adanya hubungan positif antara bonus plan dengan praktik perataan laba dapat membuktikan bahwa manajer dan pemegang saham memiliki perbedaan kepentingan, yaitu pemegang saham memiliki kepentingan untuk meningkatkan kekayaannya dalam bentuk pembagian dividen. Akan tetapi, manajer memiliki kepentingan untuk meningkatkan kesejahteraannya dalam bentuk bonus. Adanya motivasi untuk memperoleh bonus yang tinggi menyebabkan manajer berusaha memperlihatkan kinerja perusahaan yang baik. Salah satu upaya yang dapat dilakukan adalah mengelola laba yang diperoleh oleh perusahaan melalui praktik perataan laba.

Koefisien regresi dari ukuran perusahaan yaitu -0,581 dengan nilai signifikansi sebesar $0,000 \quad(<0,05)$, yang berarti bahwa ukuran perusahaan berpengaruh negatif pada praktik perataan labaatau $\mathrm{H}_{3}$ ditolak. Maka dari itu, semakin besar ukuran perusahaan maka semakin kecil kecenderungan manajer untuk melakukan praktik perataan laba, dan begitu pula sebaliknya.

Perusahaan besar umumnya mendapatkan pengawasan yang lebih ketat dari pengguna laporan keuangan dibandingkan dengan perusahaan kecil. Adanya perhatian dan pengawasan tersebut menyebabkan perusahaan besar cenderung berhati-hati dalam melakukan pelaporan keuangan, salah satunya yaitu melaporkan laba perusahaan. Disisi lain, perusahaan kecil kurang memperoleh perhatian dan pengawasan ketat. Kondisi itulah yang mendorong manajer untuk mengatur laba perusahaan sehingga dapat memperbaiki citra perusahaan, meningkatkan kepercayaan, dan sekaligus menarik calon investor untuk menanamkan modalnya. 
Adanya hubungan negatif antara ukuran perusahaan dengan praktik perataan laba dapat disebabkan karena perusahaan besar telah mengimplementasikan good corporate governance. Penelitian Pamungkas dan Muid (2013) membuktikan bahwa ukuran perusahaan berpengaruh positif terhadap implementasi good corporate governance. Semakin besar ukuran perusahaan maka semakin besar pula kesadaran manajer akan pentingnya good corporate governance.

Pada umumnya, investor lebih tertarik untuk menanamkan modalnya atau berinvestasi pada perusahaan besar. Adanya ketertarikan ini menyebabkan jumlah shareholdersdalam perusahaan menjadi meningkat, sehingga manajer selalu berupaya untuk mengurangi kesenjangan informasi antara agen dengan prinsipal melalui penerapan good corporate governance. Tingginya kesadaran untuk menerapkan good corporate governance menyebabkan perusahaan besar cenderung tidak melakukan praktik perataan laba.

Koefisien regresi dariprofitabilitas yaitu 1,672 dengan nilai signifikansi sebesar 0,073 $(>0,05)$, yang berarti bahwa profitabilitas tidak bepengaruh pada praktik perataan laba atau $\mathrm{H}_{4}$ ditolak. Maka dari itu, tinggi atau rendahnya tingkat profitabilitas tidak dapat mendorong manajer untuk melakukan praktik perataan laba. Manajer perusahaan yang melakukan praktik perataan laba secara berlebihan akan cenderung mendapatkan sorotan publik. Disamping itu, adanya praktik perataan laba juga dapat membahayakan kredibilitas dari suatu perusahaan, sehingga manajer akan berupaya untuk meminimalisir praktik perataan laba tersebut. 
Tidak berpengaruhnya profitabilitas pada praktik perataan laba juga dapat disebabkan oleh pertimbangan lain dari investor sebelum mengambil keputusan investasi. Hal ini berarti bahwa investor tidak hanya mempertimbangkan rasio profitabilitas dalam mengambil keputusan investasi, tetapi juga mempertimbangkan rasio keuangan lainnya, seperti rasio aktivitas usaha dan rasio penilaian pasar. Wiagustini (2014: 86) menjelaskan bahwa rasio aktivitas digunakan untuk mengukur efektif atau tidaknya perusahaan dalam memanfaatkan sumber dananya, sedangkan rasio penilaian pasar digunakan untuk mengukur pengakuan pasar terhadap kondisi keuangan yang dicapai oleh perusahaan.

Hasil penelitian ini memiliki dua implikasi baik secara teoretis maupun praktis. Implikasi teoretis dari penelitian ini yaitu dapat mendukung teori keagenan dan mendukung hipotesis rencana bonus dalam teori akuntansi positif. Hipotesis tersebut menjelaskan bahwa manajer berupaya untuk mengatur laba bersih perusahaan karena didasari oleh motivasi yaitu memperoleh bonus yang tinggi. Selain itu, hasil penelitian inni juga dapat dijadikan sumber referensi bagi penelitian selanjutnya yang membahas mengenai praktik perataan laba. Secara praktis, hasil penelitian ini dapat dijadikan referensi dan tambahan informasi bagi investor, kreditur, pemerintah, dan pengguna laporan keuangan lainnya.

\section{SIMPULAN}

Berdasarkan analisis yang telah dilakukan, maka dapat disimpulkan beberapa hal yaitu: 1) variabel leverage tidak berpengaruh pada praktik perataan laba, 2) variabel bonus plan berpengaruh positif pada praktik perataan laba, 3) variabel 
ukuran perusahaanberpengaruh negatif pada praktik perataan laba, serta 4) variabel profitabilitas tidak berpengaruh pada praktik perataan laba.

Adapun saran yang dapat diberikan sesuai dengan hasil penelitian dan simpulan yang ada yaitu peneliti selanjutnya diharapkan dapat menambahkan beberapa variabel bebas yang diduga mampu mempengaruhi praktik perataan laba, seperti nilai perusahaan, kepemilikan manajerial, dan kepemilikan institusional. Hal ini disebabkan karena nilai Nagelkerke $R$ Square pada penelitian ini masih cukup rendah yaitu sebesar $24,7 \%$. Selain itu, bagi pihak kreditur diharapkan dapat memperketat syarat dalam pemberian kredit, sebab perusahaan dengan leverage yang tinggi maupun perusahaan dengan leverage yang rendah memiliki kesempatan yang sama untuk melakukan praktik perataan laba. Bagi pemegang saham, diharapkan dapat meningkatkan pengawasan terhadap kinerja manajer, sehingga dapat meminimalisir praktik perataan laba yang dilakukan oleh manajer

\section{REFERENSI}

Aflatooni, A., \& Nikbakht, Z. (2009). Income Smoothing, Real Eranings Management and Long-Run Stock Returns. Business Intelligence Journal, $3(1), 55-73$.

Apriani, N. W. L., \& Wirawati, N. G. P. (2018). Pengaruh Asimetri Informasi dan Ukuran Perusahaan pada Income Smoothing dengan GCG sebagai Variabel Moderasi. E-Jurnal Akuntansi Universitas Udayana, 24(1), 741-767. https://doi.org/https://doi.org/10.24843/EJA.2018.v24.i01.p28

Astika, I. B. P. (2016). Konsep-konsep Dasar Akuntansi Keuangan. Denpasar: Udayana University Press.

Beidleman, C. R. (1973). Income Smoothing: The Role of Management. The Accounting Review, 48(4), 653-667. 
Bestivano, W. (2013). Pengaruh Ukuran Perusahaan, Umur Perusahaan, Profitabilitas, dan Leverage terhadap Perataan Laba pada Perusahaan yang Terdaftar di BEI. Jurnal Akuntansi Universitas Negeri Padang, 1(1), 1-28.

Connelly, B. L., Certo, S. T., Ireland, R. D., \& Reutzel, C. R. (2011). Signaling Theory: A Review and Assessment. Journal of Management, 37(1), 39-67.

Dewi, N. M. S. S., \& Latrini, M. Y. (2016). Pengaruh Cash Holding, Profitabilitas, dan Reputasi Auditor pada Perataan Laba. E-Jurnal Akuntansi Universitas Udayana, 15(3), 2378-2408.

Dwiputra, I. M. A., \& Suryanawa, I. K. (2016). Pengaruh Return On Assets, Net Profit Margin, Debt to Equity Ratio, Size pada Perataan Laba. E-Jurnal Akuntansi Universitas Udayana, 16(1), 129-155.

Eckel, N. (1981). The Smoothing Hypothesis Revisited, 17(1), 28-40.

Eisenhardt, K. M. (1989). Agency Theory: An Assessment and Review Link. The Academy of Management Review, 14(1), 57-74.

Enekwe, C. I., Agu, C. I., \& Nnagbogu, E. K. (2014). The Effect of Financial Leverage on Financial Performance: Evidence of Quoted Pharmaceutical Companies in Nigeria. IOSR Journal of Economics and Finance, 5(3), 1725.

Eni, I. G. A. K. R. S. M., \& Suaryana, I. G. N. A. (2018). Pengaruh Cash Holding, Profitabilitas dan Ukuran Perusahaan terhadap Perataan Laba Pada Perusahaan Properti di BEI. E-Jurnal Akuntansi Universitas Udayana, 23(3), 1682-1707. https://doi.org/https://doi.org/10.24843/EJA.2018.v23.i03.p03

Fadhli, M. (2015). Analisis Faktor-faktor yang Mempengaruhi Praktik Perataan Laba (Income Smoothing) pada Perusahaan yang Terdaftar di Bursa Efek Indonesia (Studi Empiris pada Kelompok Wholesale And Retail Trade Tahun 2010-2012). Jom Fekon, 2(1), 1-15.

Fatmawati, \& Djajanti, A. (2015). Pengaruh Ukuran Perusahaan, Profitabilitas, dan Financial Leverage terhadap Praktik Perataan Laba pada Perusahaan Manufaktur yang Terdaftar di Bursa Efek Indonesia. Jurnal Akuntansi Dan Bisnis, 2(3), 1-11.

Fischer, M., \& Rosenzweig, K. (1995). Attitude of Students and Accounting Practitioners Concerning The Ethical Acceptability of Earnings Management. Journal of Business Ethics, 14(6), 433-444.

Gayatri, I. A., \& Wirakusuma, M. G. (2013). Faktor-faktor yang Mempengaruhi Perataan Laba Perusahaan Manufaktur yang Terdaftar di Bursa Efek 
Indonesia. E-Jurnal Akuntansi Universitas Udayana, 2(1), 1-20.

Handayani, F., \& Fuad. (2015). Perusahaan Otomotif yang Terdaftar di Bursa Efek Indonesia (BEI) Periode 2009-2012. Diponegoro Journal of Accounting, 4(2), 1-12.

Hejazi, R., Ansari, Z., Sarikhani, M., \& Ebrahimi, F. (2011). The Impact of Earnings Quality and Income Smoothing on The Performance of Companies Listed in Tehran Stock Exchange. International Journal of Business and Social Science, 2(17), 193-197.

Herlina, \& Damayanthi, I. G. A. E. (2016). Good Corporate Governance sebagai Pemoderasi Pengaruh Profitabilitas pada Praktik Perataan Laba. E-Jurnal Akuntansi Universitas Udayana, 17(3), 2298-2320.

Iskandar, A. F., \& Suardana, K. A. (2016). Pengaruh Ukuran Perusahaan, Return On Asset, dan Winner/Losser Stock terhadap Praktik Perataan Laba. EJurnal Akuntansi Universitas Udayana, 14(2), 805-834.

Jensen, M. C., \& Meckling, W. H. (1976). Theory of The Firm: Managerial Behavior, Agency Costs and Ownership Structure. Journal of Financial Economics, 3(4), 305-360.

Josep, W. H., AR, M. D., \& Azizah, D. F. (2016). Pengaruh Ukuran Perusahaan, Return On Asset dan Net Profit Margin terhadap Perataan Laba (Income Smoothing) (Studi pada Perusahaan Manufaktur yang Terdaftar di BEI 20122014). Jurnal Administrasi Bisnis (JAB), 33(2), 94-103.

Kasmir. (2013). Analisis Laporan Keuangan. Jakarta: Raja Grafindo Persada.

Lahaya, I. A. (2017). Pengaruh Dividend Payout Ratio, Risiko Keuangan, Nilai Perusahaan, dan Ukuran Perusahaan terhadap Perataan Laba (Studi pada Perusahaan Manufaktur Sektor Industri Dasar dan Kimia Listing di Bursa Efek Indonesia). Jurnal Akuntansi Dan Keuangan, 14(1), 11-18.

Liu, J. (2012). Board Monitoring, Management Contracting and Earnings Management: An Evidence from ASX Listed Companies. International Journal of Economics and Finance, 4(12), 121-136.

Martinez, A. L., \& Castro, M. A. R. (2011). The smoothing hypothesis, Stock Returns and Risk in Brazil. Brazilian Administration Review, 8(1), 1-20.

Muslichah. (2015). Pengaruh Profitabilitas, Size, dan Financial Leverage terhadap Income Smoothing (Studi pada Perusahaan Manufaktur Yang Terdaftar Di Bursa Efek Indonesia). Jurnal JIBEKA, 9(2), 40-47.

Natalie, N., \& Astika, I. B. P. (2016). Pengaruh Cash Holding, Bonus Plan, 
Reputasi Auditor, Profitabilitas dan Leverage pada Income Smoothing. EJurnal Akuntansi Universitas Udayana, 15(2), 943-972.

Nejad, H. S., Zeynali, S., \& Alavi, S. S. (2013). Investigation of Income Smoothing at The Companies Listed on The Stock Exchange By the Using Index Eckel (Case Study: Tehran Stock Exchange). Asian Journal of Management Sciences and Educaition, 2(2), 49-62.

Nugroho, S., \& Darsono. (2015). Pengaruh Kompensasi, Kepemilikan Manajerial, Diversifikasi Perusahaan, dan Ukuran KAP terhadap Manajemen Laba. Diponegoro Journal of Accounting, 4(3), 1-13.

Obaidat, A. N. (2017). Income Smoothing Behavior at the Times of Political Crises. International Journal of Academic Research in Accounting, Finance and Management Sciences, 7(2), 1-13.

Pramono, O. (2013). Analisis Pengaruh ROA, NPM, DER, dan Size terhadap Praktik Perataan Laba (Studi Kasus pada Perusahaan Manufaktur yang terdaftar di Bursa Efek Indonesia Periode 2007-2011). Jurnal Ilmiah Mahasiswa Universitas Surabaya, 2(2), 1-16.

Pratiwi, N. W. P. I., \& Damayanthi, I. E. (2017). Analisis Perataan Laba dan Faktor-faktor yang Mempengaruhinya. E-Jurnal Akuntansi Universitas Udayana, 20(1), 496-525.

Putri, A. Y., Rahayu, S., \& Yudowati, S. (2016). Pengaruh Ukuran Perusahaan, Profitabilitas, dan Leverage terhadap Praktik Perataan Laba (Studi Kasus pada Perusahaan Manufaktur yang Terdaftar di Bursa Efek Indonesia Tahun 2012-2014). E-Proceeding of Management, 3(2), 1589-1595.

Putri, P. A. D. W., \& Budiasih, I. G. A. N. (2018). Pengaruh Financial Leverage, Cash Holding, dan ROA pada Income Smoothing di Bursa Efek Indonesia. E Jurnal Akuntansi Universitas Udayana, 22(3), 1936-1964. https://doi.org/https://doi.org/10.24843/EJA.2018.v22.i03.p11

Saeidi, P. (2012). The Relationship between Income Smoothing and Income Tax and Profitability Ratios in Iran Stock Market. Asian Journal of Finance \& Accounting, 4(1), 46-51.

Sari, L. R. (2014). Pengaruh Ukuran Perusahaan dan Struktur Kepemilikan terhadap Praktik Perataan Laba pada Perusahaan Manufaktur yang Terdaftar di Bursa Efek Indonesia. Jurnal Akuntansi, 2(1), 1-24.

Sidartha, A. R. M., \& Erawati, N. M. A. (2017). Pengaruh Ukuran Perusahaan dan Risiko Keuangan pada Praktik Perataan Laba dengan Variabel Pemoderasi Jenis Industri. E-Jurnal Akuntansi Universitas Udayana, 20(2), 1103-1132. 
Suryani, A. D., \& Damayanti, I. G. A. E. (2015). Pengaruh Ukuran Perusahaan, Debt to Equity Ratio, Profitabilitas dan Kepemilikan Institusional pada Perataan Laba. E-Jurnal Akuntansi Universitas Udayana, 13(1), 208-223.

Trisnawati, M., Nazar, M. R., \& Yudowati, S. P. (2017). Pengaruh Profitabilitas, Dividend Payout Ratio, dan Financial Leverage terhadap Praktik Perataan Laba. E-Proceeding of Management, 4(3), 2654-2660.

Wahyuni, A. E., Carolina, Y., \& Sambharakresna, A. (2013). Analisis Faktorfaktor yang Mempengaruhi Praktik Income Smoothing. JAFFA, 1(1), 39-52.

Wang, Z., \& William, T. H. (2011). Accounting Income Smoothing and Stockholder Wealth. Journal of Apllied Business Research.

Watts, R. L., \& Zimmerman, J. L. (1978). Towards a Positive Theory of the Determination of Accounting Standards. The Accounting Review, 53(1), 112-134.

Wiagustini, N. L. P. (2014). Manajemen Keuangan. Denpasar: Udayana University Press.

Yulia, M. (2013). Pengaruh Ukuran Perusahaan, Profitabilitas, Financial Leverage, dan Nilai Saham terhadap Perataan Laba (Income Smoothing) pada Perusahaan Manufaktur, Keuangan dan Pertambangan yang Terdaftar di Bursa Efek Indonesia (BEI). Jurnal Fakultas Ekonomi Universitas Negeri Padang, 1(2), 1-24.

Yusrilandari, L. P. (2016). Pengaruh Profitabilitas, Kepemilikan Manajerial, dan Ukuran Perusahaan terhadap Manajemen Laba. E-Proceeding of Management, 3(3), 3159-3167.

Zuhriya, S., \& Wahidahwati. (2015). Perataan Laba dan Faktor-faktor yang Mempengaruhi Perusahaan Manufaktur di BEI. Jurnal Ilmu \& Riset Akuntansi, 4(7), 1-22. 